\title{
The Influence of Digital Comic Learning Media on Primary School Students' Motivation in Social Studies
}

\section{Safira Mirosunnaily, Puri Pramudiani}

Universitas Muhammadiyah Prof. Dr. HAMKA

safiramirosunnaily@gmail.com

\section{Article History}

received 14/7/2021

\begin{abstract}
This study aims to determine the influence of digital comics learning media on primary school students' motivation in social studies. The method used in this research was experimental quantitative research. The subjects of this research were fourth grade students at MIT Fatahillah Depok, namely class IV A as control class and class IV B as experimental class, totaling 29 students for each class. The instruments used in this research were in the form of questionnaires and documentation. The data was validated using correlation product moment and to test the reliability used Cronbach's Alpha. After the data was declared valid and reliable, it was continued with the calculation of the normality test using the Lilliefors test and the homogeneity test using the Fisher test. The results of hypothesis testing in this study used the $t$ test and obtained $t_{\text {count }}$ was 4.392 and t table was 1.673. Therefore, this study proves that there is an influence of using digital comics learning media on primary school students' motivation in social studies.
\end{abstract}

Keywords: Learning Media, Digital Comic, Motivation, Social Studies, Primary School.

\section{Abstrak}

Penelitian ini bertujuan untuk mengetahui pengaruh media pembelajaran komik digital terhadap motivasi belajar IPS siswa sekolah dasar. Metode penellitian yang digunakan adalah penelitian kuantitatif eksperimen. Subjek penelitian ini adalah siswa kelas IV MIT Fatahillah Depok yaitu kelas IV A sebagai kelas kontrol dan kelas IV B sebagai kelas eksperimen yang masing-masing berjumlah 29 siswa. Instrumen yang digunakan dalam penelitian ini berupa angket dan dokumentasi. Data divalidasi menggunakan korelasi product moment dan untuk uji reliabilitas digunakan Cronbach's Alpha. Setelah data dinyatakan valid dan reliabel, dilanjutkan dengan perhitungan uji normalitas menggunakan uji Lilliefors dan uji homogenitas menggunakan uji Fisher. Hasil pengujian hipotesis dalam penelitian ini menggunakan uji $t$ dan diperoleh $t_{\text {count }}$ sebesar 4,392 dan table sebesar 1,973. Kesimpulan penelitian ini membuktikan bahwa terdapat pengaruh penggunaan media pembelajaran komik digital terhadap motivasi belajar IPS siswa sekolah dasar.

Kata kunci: Media Pembelajaran, Komik Digital, Motivasi, IImu Pengetahuan Sosial, Sekolah Dasar 


\section{INTRODUCTION}

Education is a place for humans to gain knowledge, intelligence and various experiences in life. Education is a very important activity in human life, which means that every human being in Indonesia has the right to get the opportunity to develop in it (Alpian et al., 2019). Learning is an activity in which there is a process from not knowing to knowing, from not understanding to understanding, in order to get optimal results. Learning can also be interpreted as a result of the interaction of stimulus and response (Khuluqo, 2017). In the principle of direction, educators formulate the goals of special directions or learning objectives for students. This summary is aligned with the behavioral conditions that students can apply (Dimyati \& Mudjiono, 2013). One of the principles of learning is that learning is required in a challenging realm where you are skilled at optimizing exploration abilities so that you learn effectively (Slameto, 2015).

Education takes place in three aspects, namely the family domain, the community domain, and the school domain (Kurniawan, 2015) n learning activities that take place at school, students will be taught various kinds of subjects, one of which is Social Studies Social studies education is one of the subjects presented in primary schools which includes a set of concepts, facts, events, and generalizations related to social rumors which covers material history, economics, geography, and sociology (Gunawan, 2016). The main purpose of social studies learning is to develop students' responsiveness to social problems that often occur in the community, and to have positive behavior towards the improvement of all the transformations that take place, and have the ability to overcome every problem that takes place every day, both those that occur in themselves as well as in the community (Susanto, 2014).

In March 2020, the most school activities changed to online distance learning due to Coronavirus Disease and until now the pandemic is still ongoing. The online learning process makes educators required to look for a series of activities that can fulfill students during online learning, so that the learning process remains fun. Distance learning, which has been running for 1.5 years, has an impact on students such as students feel bored, not focused and their learning motivation decreases and they cannot follow learning properly and maximally (Saumi et al., 2021). To achieve optimal learning conditions, educators must be creative and innovative in delivering the material to reach the goal. In delivering learning material, the learning process requires learning media. Learning media are teaching aids that can be used to help the learning and teaching process so that the message or information presented by educators will be more clearly observed so that educational goals will be realized effectively and efficiently (Dwijayani, 2019). The benefits of media are to shorten the learning process and maximize the advantages of the learning process (Nurseto, 2012).

Based on the results of observations made at MIT Fatahillah Depok, it was revealed that the use of learning media only used Zoom Meetings, WhatsApp Groups and pictures contained in textbooks. But it was very unfortunate, students' learning motivation has decreased due to the limited internet quota so they were often late for Zoom Meetings. The impact that occurs that students felt less enthusiastic or tend to be bored with learning so that learning becomes less interesting for them. Educators must be able to understand the characteristics of students in using appropriate learning media and be able to increase students' motivation so that students know and work on the material that has been delivered by educators. 
According to the problem mentioned, the researchers propose the innovation in the teaching and learning activities using digital comics learning media. Digital comics fall into the category of visual learning media. Visual learning media is a system of presenting material from the source to the recipient of the material through visual media intermediaries, with the aim of being able to stimulate the thoughts, interests, feelings, and attention of students so that the learning process takes place (Mumtahabah, 2014). Comics are included in the verbal cartoon category, because comics present communication sentences contained in balloons that show conversations with the aim of helping readers understand information even though the sentences in comics are not dominant. The cartoon illustrations contained in the comics are presented in the form of these panels, presenting sustainable elements (Yunia, 2017).

According to the research result conducted by (Putri, 2017) and (Riwanto \& Wulandari, 2018) those were explained that there is a significant influence of using digital comics in the learning process. Based on the problems mentioned, the researchers formulate the research question namely "Is there any influence of using digital comics learning media on students' learning motivation in social studies for fourth grade students at MIT Fatahillah Depok?" This study aims to determine whether the application of digital comics learning media has an influence on students' learning motivation in social studies for fourth-grade students at MIT Fatahillah Depok. The researchers also want to provide learning media innovations in teaching creativity through applying digital comics learning media.

\section{RESEARCH METHOD}

The method of this research was experimental quantitative research using the Quasi Experiment method with Post-test Only Control Design (Sugiyono, 2016). The population is a generalization area consisting of objects or subjects that have certain quantities and characteristics determined by the researchers to be studied and then concluded (Kusdiwelirawan, 2014). The population of this study were all fourth graders as many as 58 students. The technique used in this study is the Non Probability Sampling technique with the type of saturated sample, the assumption of taking all members of the population. The sample in this study amounted to 58 students from classes IV-A and IV-B in which each class has the number of 29 students.

The data obtained through the test technique. The test used to collect data regarding students' learning motivation that was provided in the form of a questionnaire containing 25 statements. This research instrument used a questionnaire with a Likert scale, where the respondents gave a checklist mark. Calculation of validity test used Product Moment, and reliability test using Cronbach's Alpha. Normality test used Lilliefors, and homogeneity test used Fisher test. While hypothesis test used t-test. The statistical technique used in this research was descriptive statistical technique.

\section{RESULTS AND DISCUSSION}

Based on the results of the validity test of the questionnaire instrument totaling 34 questionnaire statements after being tested, then it was obtained 25 questionnaire statements that could be declared valid. This means that 9 questionnaire statements were declared invalid (drop) because $r_{\text {count }}<r_{\text {table }}$ with 30 students was 0.361 .

Based on statistical analysis and the results of post-test that the highest value reached by the experimental class was 107, and the control class achieved the highest score of 105 . The lowest score obtained by the experimental class was 90 , while the 
control class got the lowest score of 75 . The following table describes the results of the post-test questionnaire on learning motivation and digital comics learning media for the experimental class and the control class.

Table 1 Data Result of Post-test Questionnaire Experiment Class

\begin{tabular}{cccccccc}
\hline Highest & $\begin{array}{c}\text { score } \\
\text { Lowest } \\
\text { score }\end{array}$ & Mean & Median & $\begin{array}{c}\text { Mode } \\
\text { of }\end{array}$ & variance & $\begin{array}{c}\text { Standard } \\
\text { deviation }\end{array}$ & N \\
\hline 107 & 90 & 99,896 & 102 & 102 & 28,906 & 5,187 & 29 \\
\hline
\end{tabular}

Table 2 Data Result of Post-test Questionnaire Control Class

\begin{tabular}{cccccccc}
\hline Highest & $\begin{array}{c}\text { score } \\
\text { Lowest } \\
\text { score }\end{array}$ & Mean & Median & $\begin{array}{c}\text { Mode } \\
\text { of }\end{array}$ & variance & $\begin{array}{c}\text { Standard } \\
\text { deviation }\end{array}$ & N \\
\hline 105 & 75 & 92,966 & 93 & 92 & 46,106 & 6,790 & 29 \\
\hline
\end{tabular}

This study was conducted using a test for normality using Lilliefors test. It was carried out with a significant level of $=0.05$ on the number of respondents in the experimental class 29 respondents and the control class with 29 respondents. So it showed $L_{\text {count }}<$ Ltable.

Table 3 Calculation Results of Normality Test

\begin{tabular}{|c|c|c|c|c|}
\hline Class & $\mathrm{L}_{\text {count }}$ & $\mathbf{L}_{\text {Table }}$ & Criteria & Description \\
\hline Control & 0.089 & 0.165 & \multirow{2}{*}{$L_{\text {count }}<L_{\text {table }}$} & \multirow{2}{*}{$\begin{array}{c}\text { normal } \\
\text { distribution }\end{array}$} \\
\hline Experiments & 0.143 & 0.165 & & \\
\hline
\end{tabular}

Homogeneity test conducted on motivation to learn from the experimental class control class with Fisher formula test. From the calculation results then obtain the value of $F_{\text {table }}$ is 1,882 and $F_{\text {count }}$ is 1,173 with degree of freedom numerator $=28$, degree of freedom denominator $=28$ and significant level $=0,05 \%$. From the results, it was shown that the data is homogeneous.

Table 4 Result Calculation of Homogeneity

\begin{tabular}{lccccc}
\hline \multicolumn{1}{c}{ Groups } & Variance & $\mathbf{F}_{\text {count }}$ & $\mathbf{F}_{\text {table }}$ & Criteria & Information \\
\cline { 1 - 2 } Control & 46,106 & \multirow{2}{*}{1,713} & 1,882 & $1,713<1,882$ & $\begin{array}{c}\text { Homogeneous } \\
\text { Data }\end{array}$ \\
\cline { 1 - 2 } Experimental & 26,909 & & & &
\end{tabular}


Hypothesis testing using T-test. In the t-test calculation the results obtained $t_{\text {count }}$ is 4,392 and $t_{\text {table }}$ is 1,973 . Then $t_{\text {count }}>t_{\text {table. }}$. Based on the $t$-test, it can be concluded that there is an influence of digital comics learning media on social studies learning motivation.

Table 5 Hypothesis Test Results Data

\begin{tabular}{|c|c|c|c|c|c|c|}
\hline Class & Mean & $\mathrm{Db}$ & $\mathbf{T}_{\text {arithmetic }}$ & $T_{\text {table }}$ & Criteria & Information \\
\hline Control & 92,966 & & & & & \\
\hline Experimental & $\begin{array}{l}99,862 \\
\text { tested }\end{array}$ & 56 & 4,392 & 1,673 & $4,392>1,673$ & $\begin{array}{c}\text { There is an } \\
\text { influence }\end{array}$ \\
\hline
\end{tabular}

The hypothesis is

Description:

$\mathrm{H}_{0} \quad$ : There is no influence of digital comics learning media on social studies learning motivation

$\mathrm{H}_{1} \quad$ : There is an influence of digital comics learning media on social studies learning motivation.
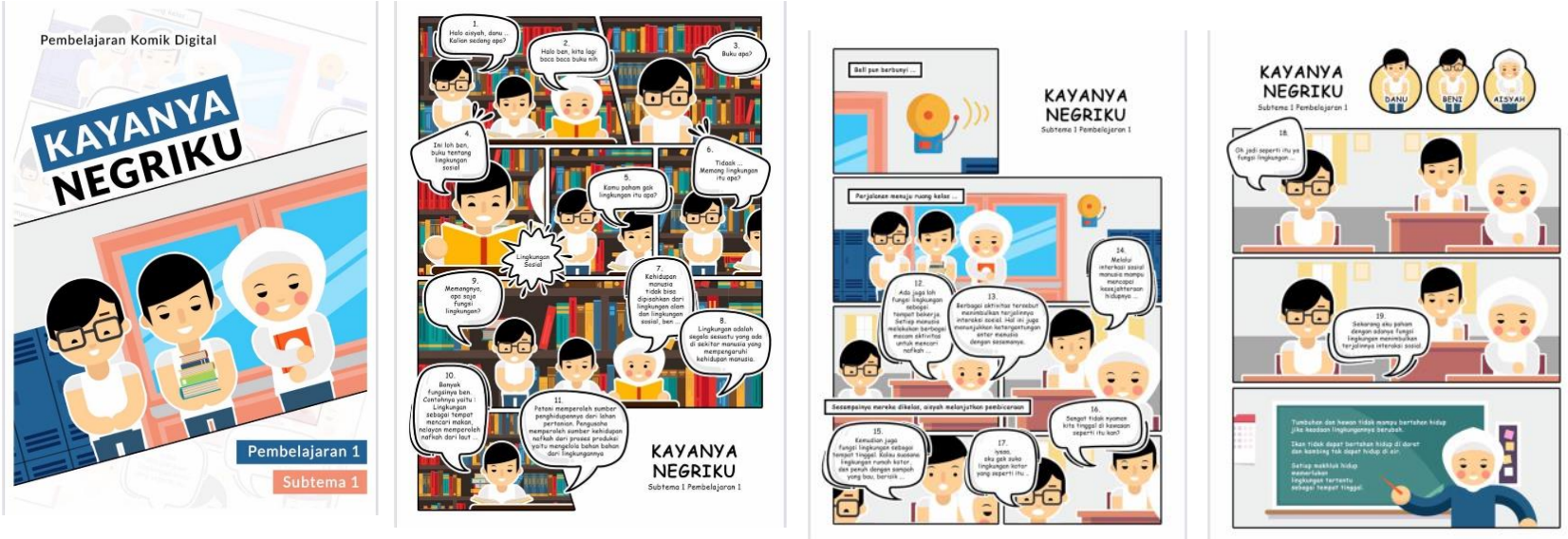

\section{Picture 1 Digital Comic Learning Media}

In this research, the researchers created the digital comic learning media by themselves using Adobe Photoshop application. The advantage of this digital comic media is that it is full off colors and pictures. In this digital comic, there are also numbers in the dialogue balloons to make it easier for students to read.

Before conducting the research, the validity and reliability tests of the questionnaire statement items were tested. The results of the validity test and reliability test of the statement items were declared valid and reliable. The calculation of $r_{\text {count }}$ has met the requirements because it is greater than 0,70 (Yusup, 2018) which means that the instrument can be declared reliable and feasible to be used. The learning process in the experimental class was carried out using digital comics learning media, while learning in the control class students were given material in the form of power point via 
WhatsApp Group, in which the teachers at MIT Fatahillah Depok usually used to do the learning process. At the end of the lesson, post-test was conducted in the control class and the experimental class. Furthermore, the data for the two classes were analyzed for normality test using Lilliefors. If the distribution of the data obtained was normal, then the homogeneity test was calculated using Fisher test.

The data from the analysis requirements test which includes the normality test and homogeneity test, can be tested using the T-test formula. Table 5 shows that obtaining the results of the calculation of $t_{\text {count }}>t_{t a b l e}$ which was $4,392>1,673$. Therefore, it can be stated that $\mathrm{H}_{0}$ was rejected, which means that there is an influence of digital comics learning media on the social studies learning motivation of fourth grade students at MIT Fatahillah Depok. This is in line with Alannasir (2016) who argues that students' learning motivation in the social studies shows the transformation of learning motivation in students which can be seen from before and after learning by applying animated learning media has increased significantly. Relevant to Halidi \& Husain (2015) that the application of ICT learning media in the fifth-grade science learning process can increase students' motivation and learning. Based on the results of this study, it can be proven that the effect of using digital comics learning media on social studies learning motivation is not a coincidence, but because of the treatment given to the experimental class. This is in line with the statement of Mahidin (2017) stated that the application of interactive learning media has real variations in increasing students' critical thinking skills. It is also relevant to Fatahullah (2016) stated that the category of students who have low critical thinking skills obtained a significant difference in social studies learning outcomes between the categories of students who were treated with Adobe Flash-based animation learning media and the categories of students who were given power point-based learning media treatment. .

Each individual has different abilities, including the researchers who have limitations in conducting research. In this study, because it was carried out through online so that there were limitations of the internet network for some students. Beside that, this research was conducted in a short time due to the provisions at school in which the students would encounter the final examination.

\section{CONCLUSION}

Based on the results of the research, it can be concluded that there is an influence of digital comics learning media on social studies learning motivation. In addition to increasing social studies learning motivation, this learning media emphasizes students to play an active role in the learning process. Digital comics learning media can not only be applied to social studies subjects, but can be applied to other subjects, so that these students can accept and understand other learning, and understand learning with fun media. The learning process using digital comic learning media has been successfully applied in the experimental class so that it can help student accept and understand learning materials more easily, and students feel happy in learning social studies.

\section{REFERENCES}

Alannasir, W. (2016). Pengaruh Penggunaan Media Animasi dalam Pembelajaran IPS. Journal of Educational Science and Technology (EST), 2(2), 81. https://doi.org/10.26858/est.v2i2.2561

Alpian, Y., Anggraeni, S. W., Wiharti, U., \& Soleha, N. M. (2019). Pentingnya Pendidikan Bagi Manusia. Buana Pengabdian, 1(1), 41-57. 
https://doi.org/https://doi.org/10.36805/jurnalbuanapengabdian.v1i1.581

Dimyati, \& Mudjiono. (2013). Belajar \& Pembelajaran (ke-5). Rineka Cipta.

Dwijayani, N. M. (2019). Development of circle learning media to improve student learning outcomes. Journal of Physics: Conference Series, 1321(2), 171-187. https://doi.org/10.1088/1742-6596/1321/2/022099

Fatahullah, M. M. (2016). Pengaruh Media Pembelajaran dan Kemampuan Berpikir Kritis Terhadap Hasil Belajar IPS. Jurnal Pendidikan Dasar, 7(2), 237-252. https://doi.org/https://doi.org/10.21009/JPD.072.05

Gunawan, R. (2016). Pendidikan IPS Filosofi, Konsep, dan Aplikasi (Edisi Revisi) (ke3). Alfabeta.

Halidi, H. M., \& Husain, S. N. (2015). Pengaruh Media Pembelajaran Berbasis TIK Terhadap Motivasi dan Hasil Belajar IPA Siswa Kelas V SDN Model Terpadu Madani Palu. Mitra Sains, 3(1), 53-60.

Khuluqo, insana el. (2017). Belajar dan Pembelajaran (ke-1). PUSTAKA BELAJAR.

Kurniawan, M. I. (2015). Tri Pusat Pendidikan Sebagai Sarana Pendidikan Karakter Anak Sekolah Dasar. PEDAGOGIA: Jurnal Pendidikan, 4(1), 41. https://doi.org/10.21070/pedagogia.v4i1.71

Kusdiwelirawan. (2014). Statistika Pendidikan (3rd ed.). Uhamka press.

Mahidin, Z. A. (2017). Pengaruh Media Pembelajaran Interaktif Terhadap Peningkatkan Keterampilan Berpikir Kritis Siswa. Jurnal Pendidikan Sains Indonesia (Indonesian Journal of Science Education), 5(1), 72-80.

Mumtahabah, N. (2014). Penggunaan Media Visual dalam Pembelajaran PAI. AL HIKMAH Jurnal Studi Keislaman, 4(1), 2-14.

Nurseto, T. (2012). Membuat Media Pembelajaran yang Menarik. Jurnal Ekonomi dan Pendidikan, 8(1), 19-35. https://doi.org/10.21831/jep.v8i1.706

Putri, W. N. (2017). Pengaruh Media Pembelajaran Terhadap Motivasi Belajar Bahasa Arab Madrasah Tsanawiyah. LISANIA:Journal Of Arabic Education and Literature, 1(1), 1-16. https://doi.org/https://doi.org/10.18326/lisania.v1i1.1-16

Riwanto, M. A., \& Wulandari, M. P. (2018). Efektivitas Penggunaan Media Komik Digital (Cartoon Story Maker) dalam Pembelajaran Tema Selalu Berhemat Energi. Pancar, 2(1), 14-18. https://ejournal.unugha.ac.id/index.php/pancar/article/viewFile/195/160

Saumi, N. N., Murtono, M., \& Ismaya, E. A. (2021). Peran Guru dalam Memberikan Motivasi Belajar Siswa Sekolah Dasar Pada Masa Pandemi COVID-19. Jurnal Educatio FKIP UNMA, 7(1), 149-155. https://doi.org/10.31949/educatio.v7i1.892

Slameto. (2015). Belajar dan Faktor-Faktor Yang Mempengaruhinya (ke-6). Rineka Cipta.

Sugiyono. (2016). Metode Penelitian Kuantitatif, Kualitatif, dan Kombinasi (Mixed Methods) (ke-3). Alfabeta.

Susanto, A. (2014). Teori Belajar \& Pembelajaran di Sekolah Dasar. Kencana.

Yunia, N. (2017). Pengembangan Media Pembelajaran Komok Digital Biologi Berbasis Nilai Karakter Pada Materi Pokok Sistem Pencernaan Makanan Untuk Kelas VIII MTS Negri 1 Bandar Lampung. Raden Intan Repository, 4, 9-15.

Yusup, F. (2018). Uji Validitas dan Reliabilitas Instrumen Penelitian Kuantitatif. Jurnal Tarbiyah: Jurnal IImiah Kependidikan, 7(1), 17-23. https://doi.org/10.18592/tarbiyah.v7i1.2100 